\title{
Measurement of Sub-Lethal Toxicity and Effect of Kerosene Pollutant on Hematological Profile of African Catfish (Clarias gariepinus)
}

\author{
E. A. Ivon ${ }^{1}$, F. O. Sanusi-Jadesola ${ }^{2}$, N. E. Edu ${ }^{3}$, C. O. Anyanwu ${ }^{1}$, G. M. Ubi ${ }^{3^{*}}$ \\ and Edodi lyam Odum ${ }^{1}$ \\ ${ }^{1}$ Department of Science, Laboratory Technology, Faculty of Biological Science, University of Calabar, \\ Calabar, Nigeria. \\ ${ }^{2}$ Department of Fisheries and Aquaculture, Crescent University, Ogun State, Nigeria. \\ ${ }^{3}$ Department of Genetics and Biotechnology, Faculty of Biological Sciences, University of Calabar, \\ Nigeria.

\section{Authors' contributions} \\ This work was carried out in collaboration among all authors. Author EAl initiated the idea, coin the \\ topic and drafted the manuscript. FOSJ, NEE, COA, GMU all carried out the analysis of the data \\ generated from the study. COA and FOSJ search the literature. All authors read and approved the \\ final manuscript. \\ Article Information \\ DOI: 10.9734/ARRB/2021/v36i830406 \\ Editor(s): \\ (1) Dr. Md. Torequl Islam, Federal University of Piaui, Brazil. \\ Reviewers: \\ (1) S. Narayani, Pondicherry University, India. \\ (2) Sami MILI, Higher Institute of Fisheries and Aquaculture of Bizerte, Tunisia. \\ Complete Peer review History: https://www.sdiarticle4.com/review-history/69337
}

Original Research Article

Received 03 May 2021

Accepted 11 June 2021 Published 02 August 2021

\section{ABSTRACT}

Background and Objectives: The study measured the impact of crude oil fractions and its derivatives like kerosene on the early life and sub-adults growth of African catfish, Clarias gariepinus in terms of mild, acute and chronic toxicity effect. It also examines the effect of indiscriminate spillage of crude oil derivatives on aquatic organisms.

Materials and Methods: Blood profiles such as Red Blood Cell count (RBC), White Blood Cell count (WBC), Blood Differentials, Hemoglobin, (HB), and Packed Cell Volume (PCV) of the treated fishes and control were estimated after exposure of the fish to the kerosene pollutant. Behavioral changes in fish exposed to $8.0 \mathrm{ml} / \mathrm{l}, 16.0 \mathrm{ml} / \mathrm{l}, 25.0 \mathrm{ml} / \mathrm{l}$ and $50.0 \mathrm{ml} / \mathrm{l}$ of kerosene pollutant varied from erratic swimming, moribund movement, jumping and lack of balance.

Results: At concentration $8.0 \mathrm{ml} / \mathrm{L}$, mean total mortality was observed within $72 \mathrm{hours}$ of exposure. The lethal concentration (LC50) was $8.0 \mathrm{ml} / \mathrm{L}$ and highest mean mortality observed with $80 \%$ 
kerosene pollutant. PCV of the exposed fish was $26 \%$ when compared to the control $27 \%$, HB was $8.9 \mathrm{gdl}$ as against $9.0 \mathrm{gdl}$ in the control. Total WBC was $640 \times 109 / \mathrm{L}$ as against $1280 \times 109 / \mathrm{L}$ in control. RBC reading was 2.1 compared to $5.3 \mathrm{~mm}^{3}$ of the control. Lymphocyte was $80 \%$, Neutrophil was $4 \%$ and monocyte $16 \%$ compared to $62 \%, 8 \%$ and $30 \%$ in control respectively. There was decrease in white blood cells counts for 8.0, 16.0, 25.0 and 50.0ml/L groups $(p<0.05)$ compared to the control.

Conclusion: The study concludes that it is necessary to ensure the safety of aquatic life forms especially fishes, by minimizing aquatic pollution with kerosene to sustain fish food quality, availability and security.

Keywords: Blood quality, kerosene fractions, fish behavior, lethal concentrations, Clariasgarienpinus.

ABBREVIATIONS

$\begin{array}{ll}H B & : \text { Hemoglobin } \\ \text { WBC } & : \text { White blood cells } \\ R B C & : \text { Red blood cells } \\ P C V & : \text { Packcell volume } \\ \text { LC } & : \text { Lethal concentration } \\ \text { EDTA } & \text { : Ethylene di-amine tetraamino acid } \\ \text { LABS } & \text { :Linear Alkyl Benzene Sulphonate } \\ & \text { (LABS), } \\ \text { STPP } & \text { : Sodium tripolyphosphate (STPP) }\end{array}$

\section{INTRODUCTION}

The incessant crude oil and its derivative spillage and pollution in Nigeria and the resultant spoilage of valuable fish foods inform the need for this study. The Pollution occurs either on land, air or water. Man depends heavily on water for domestic, industrial and agricultural uses. Poorer water quality means water pollution [1]. No nation is completely free from the global menace of water pollution [2]. This era of globalization and industrialization has sky rocketed the rates of aquatic pollution due to the increasing volume of industrial and domestic effluents that find their way into fresh water and marine habitats, thus altering the balance of these ecosystems [3]. Most chemicals exhibit deleterious effects on the aquatic environment if not properly handled or controlled. Industrial products beneficial to man can also pose serious threats to man and the entire environment [4]. Most of the commonly used industrial products in Calabar, Nigeria include kerosene (energy source for the commons), detergent, fertilizers and a host of others [5]. Pollution is a global menace that affects all ecological habitats. It is the introduction of foreign toxic substances capable of causing harm to man and the entire environment [6]. The heightened activities of exploration and exploitation of crude oil in the Niger Delta region of Nigeria has elicited the spillage of crude oil and its derivatives like kerosene into surrounding water bodies thus rendering the water and other life forms therein unfit for utilization of any sort or kind [7].

kerosene was the major refinery product for several decades until the advent of the electric lamp reduced its value for lighting [8]. Production further declined as the rise of the automobile established gasoline as an important petroleum product. Nevertheless, in many parts of the world, kerosene is still a common heating and cooking fuel as well as a fuel for lamps especially for the low and middle income earners who dominate the study area. Standard commercial jet fuel is essentially high-quality straight-run kerosene, and many military jet fuels are blends based on kerosene [9]. Despite reported cases of rapid uptake of crude oil derivatives like kerosene from water by fish and the concomitant bioaccumulation that do occur [10], little is been known about range findings behavior, sub-lethal toxicity, hematological impact, metabolism and acute toxicity level in African catfish, Clarias gariepinus.in Calabar, Cross River State, Nigeria. This is as a result of high level of aquatic pollution from crude oil spillage in the area.

The African catfish (Clariasgariepinus) African catfish (C. gariepinus) are sharp tooth catfish, eel-like in nature, usuallydark gray or black with coloration on the back, fading to a white belly. In Africa, thecatfish has been reported as being second in size only to the Vundu of the Zambesianwaters [11]. Because of its wide mouth, it is able to swallow relatively large prey whole. It is able to crawl on dry groundto escape drying pools and it is also able to survive in shallow mud for long periods of time in between raining seasons [12]. It spawns around inundated areas of river, lakes and streams mostly at nights [13]. One of the reasons for the choice of this genus of fish for this research work is because it has been found tobe a biomarker in the aquatic environment [14]. Other reasons for this choice of this fish includes its' hardiness and ability to tolerate adverse water quality conditions, its 
ability to grows fast and feed on large variety of agriculture by products and its ability to tolerates difficult conditions in captivity [15].

The high demand for this giant African catfish, owing to its rapid growth and flavor, necessitated an investigation into the effect of this kerosene which is the common household energy sources, on juveniles and sub-adults life forms of the fishes stocked on water polluted with kerosene and other crude oil derivatives. [16] posited that about five million red blood cells (RBC) are contained in one cubic milliliter $\left(1 \mathrm{~m}^{3}\right)$ of blood sample of vertebrates [17]. reported that the exposure of fish to crude oil fractions such as kerosene compounds resulted in the destruction of the RBC and WBC components of the blood as well as the alteration of the immune response and liver metabolism among other damages especially to the juveniles and sub-adults.

Hence, a detail haematological analysis is therefore required to determine the effect of crude oil fractions like kerosene infiltration into the juvenile and sub-adults catfish blood systems and the subsequent toxicity it impacts on the fishes. It has been reported that the uptake of crude oil fractions by fishes in water bodies and the subsequent translocation of the fractionated compounds in fish is through the gills, gut or the intestinal walls [18], where the compounds solubilizes the cell membranes and are carried via the erythrocytes to the general circulation of the blood.

Thus the response of sub-adults of African catfish (Clariasgariepinus) to kerosene related water pollution is determine by changes through expressions of several key enzymes and the biotransformation systems which include mild, acute and chronic toxicity of the pollutants to the marine life forms and the attendant bioaccumulation and biomagnifications [19] in the food chain. Hence, the study sought to measure the impact of indiscriminate spillage of crude oil fractions and its derivatives like kerosene on the blood parameters in early life and sub-adults growth of African catfish, Clarias gariepinus in aquatic ecosystem in terms of mild, acute and chronic toxicity.

\section{MATERIALS AND METHODS}

\subsection{Study Location}

The University of Calabar is located in between the Calabar municipality and Calabar south local government areas of Cross River State, Nigeria. The study was carried out in the laboratory of the Department of Zoology and Environmental biology, University of Calabar, from March, 2016 to June, 2019. It is bounded to the east by the great quo river,Calabar is the capital of Cross River State, Nigeria. It is located geographically at 40 57" North 80191 0' East. Cross River State is one of the States in the Niger Delta, South South Region of Nigeria. The State shares a maritime boundary with Cameroon in the east, Akwalbom State in the South, Abia and Ebonyi States in the West and Benue State in the North. It is geographically located at $50451 \mathrm{~N}, 80301 \mathrm{E}$ $150751 \mathrm{~N}, 8.50 \mathrm{E},[20]$. The State according to National Population Commission (NPC) [21] has a population of 3.2 million people with a land mass of 20, $156 \mathrm{~km} 2$ $(7,782$ sqm $)$.

Activities in the rural areas are mainly agriculture and petty-trading, the urban areas are characterized by heavy commercial activities, industrialization and tertiary education. Fish farming is also one of the major human activities in both rural and urban areas of the study location [21].

\subsection{The Fish Farm}

The University of Calabar Fish Farm is located about 1 kilometer away from the research laboratory (Fig.1). The fish farm harbours various sizes and species of fishes ranging from fry, fingerlings sub adults and adults. This research was carried out in the Fish Pathology Laboratory of the Faculty of Oceanography, University of Calabar. Collection of samples and gathering of materials was preceded by a thorough reconnaissance survey.

\subsection{Sources of the Pollutants}

The kerosene was purchased from Ekoson filling Station, Calabar in Cross River State, Nigeria.

\subsection{Field Investigation}

A trip was taken to the university of Calabar fish farm to ascertain the availability of African catfish (Clariasgariepinus) sub adults. After confirming the availability, the desired quantity was booked for. Similarly, the chosen toxicants were sort for in the various shops in Calabar. 


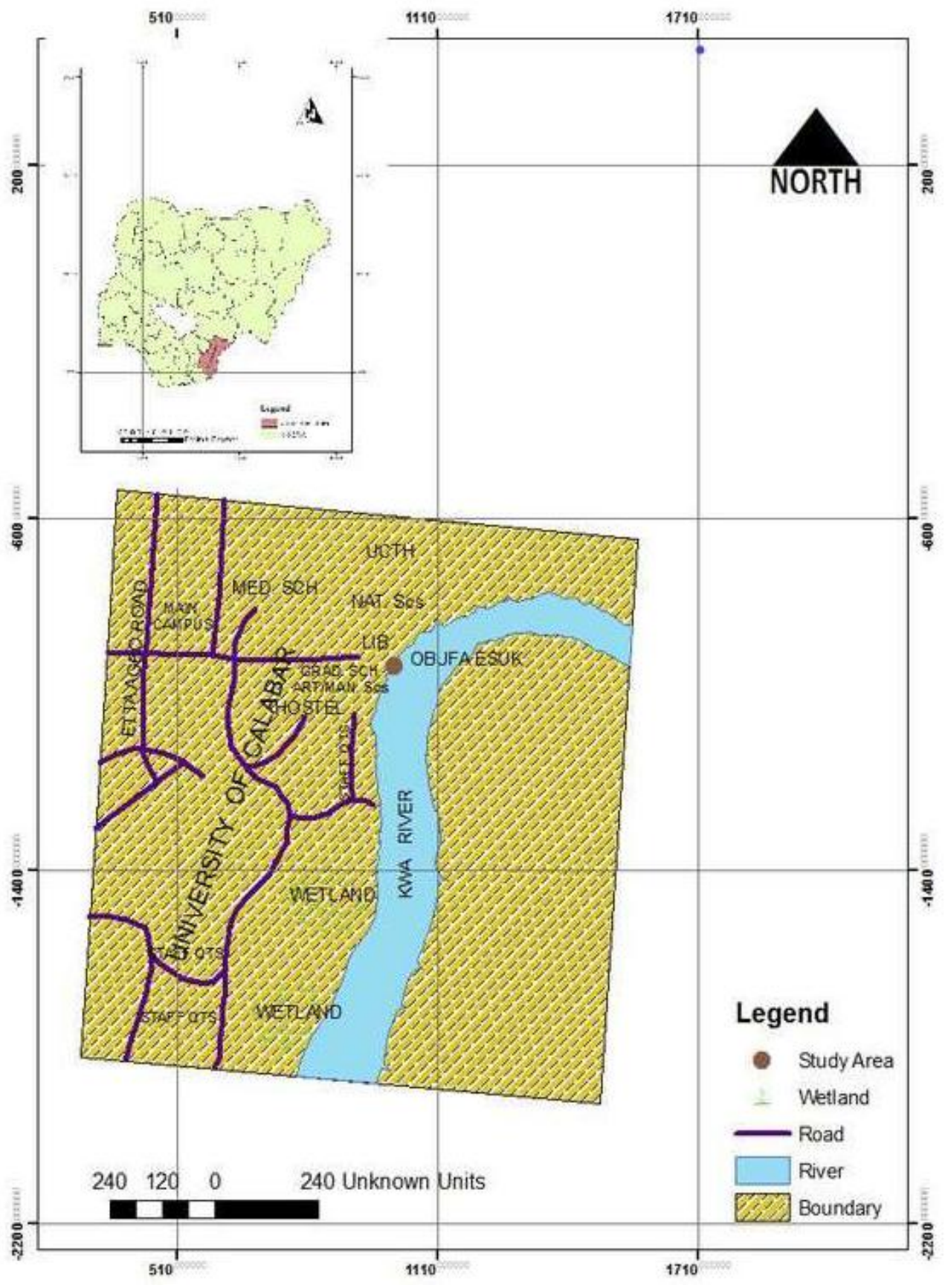

Fig. 1. Map of the University of Calabar showing the fish farm (Source: https://www.unical.edu.ng./handbook)

\subsubsection{Collection and transportation of the study fish}

A total of 600 C. gariepinussub adults with a mean weight of $8.5 \pm 0.2 \mathrm{~g}$ were purchased from the University of Calabar fish farm. Samples were carefully collected and transferred into a plastic container and transported to the Faculty of Oceanography, University of Calabar, Cross River State, Nigeria. The study fishes were transported to the laboratory in transparent plastic containers by car [22] to the laboratory which is about five min. drive from the fish farm. 


\subsubsection{Laboratory studies}

A whole day was used in arranging the laboratory. Unwanted and obstructive materials were removed and the needed aquaria thoroughly washed and dried. The laboratory was thoroughly disinfected.

\subsection{Acclimatization of Study Specimens}

The sub adult fish were transferred into a laboratory aquarium $(80 \times 30 \times 30 \mathrm{~cm} 3)$ and allowed to acclimatize in this holding tank in the laboratory condition for one weeks at a temperature $30.02 \pm 0.090 \mathrm{C}$ and $\mathrm{a} \mathrm{pH}$ of 8 , the sub adults were fed once daily with commercial feed (Copen's) at $5 \%$ of their body weight. The unconsumed feeds and faeces were removed from the holding tank and the water in the tank was changed every 24 hours as recommended by [23].

\subsection{Pollutants Used for Experiments}

The pollutants selected for the experiment is the crude oil derived kerosene which chemical formula is shown in Fig. 2 below.

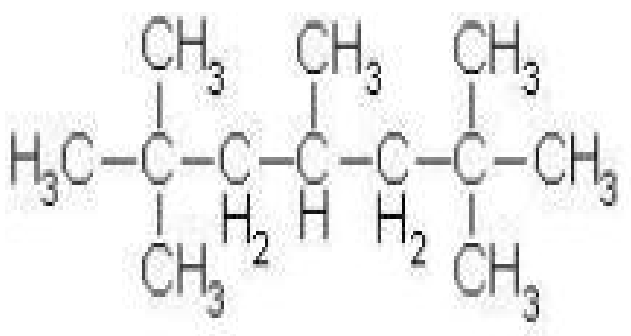

Fig. 2. Chemical structure of kerosene

\subsection{Stocking of the Test fish}

Ten (10) sub adults were carefully were introduced to each of the plastic aquaria (Fig. 3A) containing the measured toxicant and another ten (10) introduced to the control aquaria (Fig. 3B) using a hand sieve [24]. This procedure was repeated for all the experiments.

\subsection{Range Finding Tests}

Series of range finding tests were conducted using the different concentrations of the toxicant on the sub-adult fish to determine the concentration boundaries before the actual experiment.

\subsection{Toxicity Experiments with Kerosene}

The experiment was carried out in triplicates of four treatments i.e. $0.00 \mathrm{ml} / \mathrm{L}$ (control), $8.0 \mathrm{ml} / \mathrm{L}$, $16.0 \mathrm{ml} / \mathrm{L}$ and $25.0 \mathrm{ml} / \mathrm{L}$ and $50.0 \mathrm{ml} / \mathrm{L}$ (Fig. $3 \mathrm{~A}$ ). Ten (10) sub adults of $C$. gariepinus were stocked in each of the four glass aquaria $(25 \mathrm{x}$ $15.5 \times 15.5 \mathrm{~cm} 3)$ in triplicates and used for the experiment. The experiment was monitored periodically; observation and responses were taken at intervals of 24, 48, 72 and 96hour respectively.

\subsection{Haematological Studies (Blood Profile)}

Collection of blood samples from the treated and control fishes were obtained by inserting a needle directly from the anterior part of the anal fin about $2-5 \mathrm{~mm}$ behind the genital papilla to draw the desired amount of blood. Blood profiles such as Red Blood Cell count (RBC), White Blood Cell count (WBC), Blood Differentials, Hemoglobin, (HB), and Packed Cell Volume $(\mathrm{PCV})$ of the treated fishes and control were estimated after exposure of the fish to the kerosene toxicity. The Haematological indices were carried out at the Hematology Department of the University of Calabar Teaching Hospital, Calabar, Cross River, Nigeria. Blood samples were collected from the fish into anticoagulant (EDTA) bottles and rocked gently to ensure proper mixing while avoiding hemolysis.

\subsection{Statistical Analysis}

Data generated from the study were analyzed using analysis of variances (ANOVA) for significant difference $(p<0.05)$ at $95 \%$ confidence limit. Significant treatment means were separated using the Fischers' least significant difference (LSD) test.

\section{RESULTS}

3.1 Fig. 3 shows the results of a lethal concentraton on a probit curve of concentrations 8.0, 16.0, 25.0 and $50.0 \mathrm{ml} / \mathrm{l}$ generated against mean mortalities. It showed the mean lethal concentration (LC50) at which the kerosene toxicant killed $50 \%$ of the test fish, C.gariepinusat $8 \mathrm{~m} / \mathrm{l}$ as shown in Fig. 3. This was accessed from all the replicates. 
A
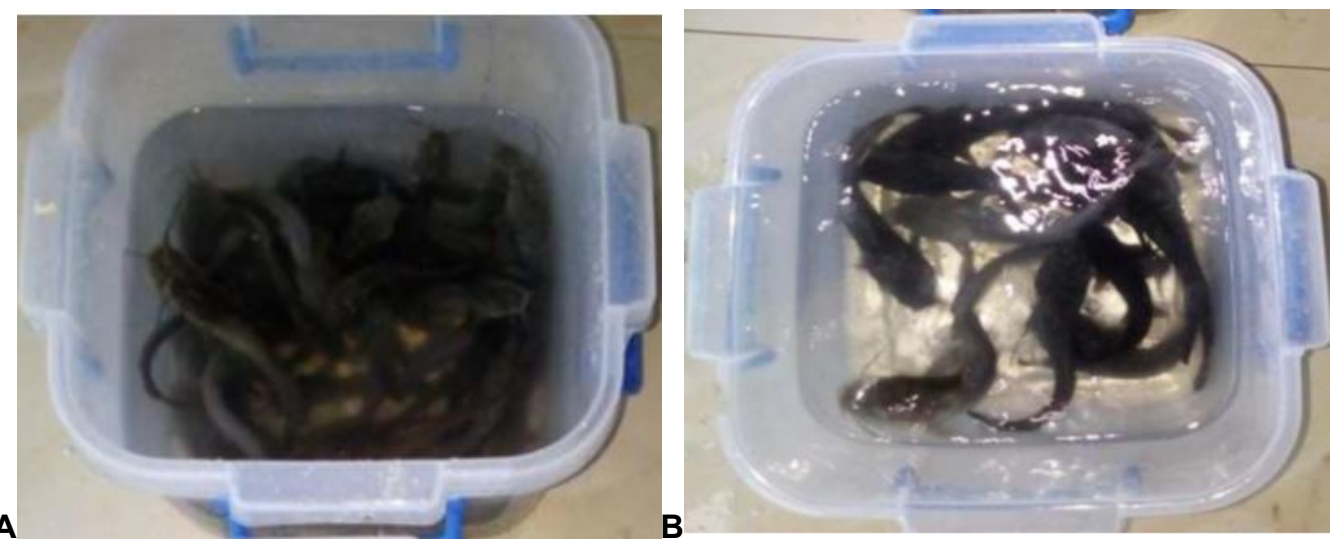

Fig. 3A. African Catfish (Clariasgarienpinus) in control water

Fig. 3B. African catfish (Clariasgarienpinus) in Kerosene submerge water

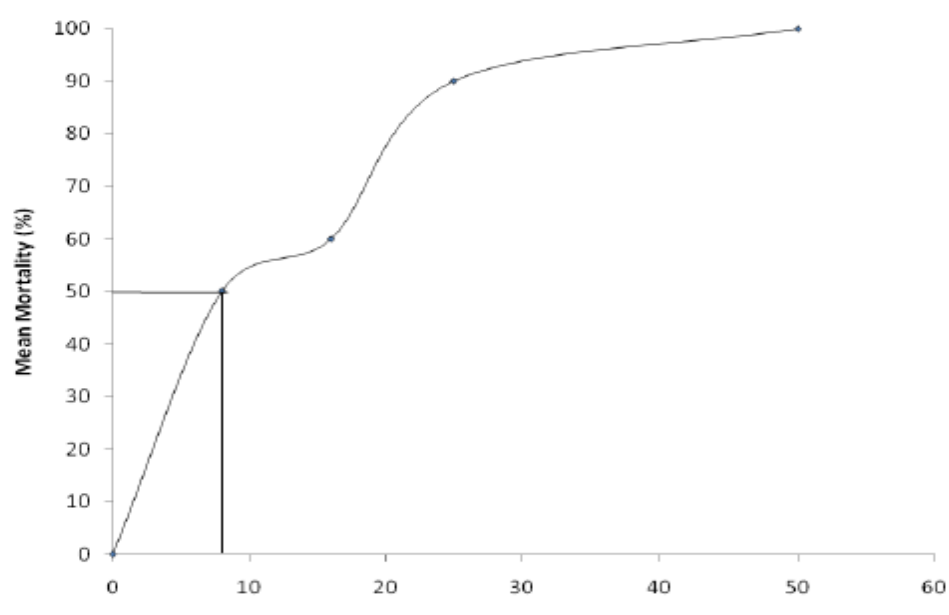

Concentration $(\mathrm{ml} / \mathrm{L})$ of kerosene

$$
\mathrm{LC}_{50}=8 \mathrm{ml} / \mathrm{L}
$$

Fig. 4. Graph of concentration against percent mortality showing $\mathrm{LC}_{50}=8 \mathrm{ml} / \mathrm{L}$ of kerosene Table 1.Range findings behavior of Clariasgarienpinus at 24, 48, 72, and $96 \mathrm{~h}$ of exposure to different concentrations of Kerosene

\begin{tabular}{|c|c|c|c|c|c|c|c|c|}
\hline & Mean & Fish & Mortality & Observation & & & & \\
\hline $\begin{array}{l}\text { Conc. Of } \\
\text { Kerosene } \\
(\mathrm{ml} / \mathrm{l})\end{array}$ & $24 \mathrm{~h}$ & $48 h$ & $72 h$ & $96 \mathrm{~h}$ & Mortality & SD & $\begin{array}{l}\text { Mean } \\
\text { Mortality }\end{array}$ & $\begin{array}{l}\% \\
\text { Behavioural } \\
\text { change }\end{array}$ \\
\hline $\begin{array}{l}\text { Control } \\
(0.0)\end{array}$ & 0 & 0 & 0 & & 0 & 0.0 & 0.0 & Normal \\
\hline 8.0 & 1 & 1 & 2 & 1 & 5 & & 50 & $\begin{array}{l}\text { Erratic } \\
\text { swimming and } \\
\text { fish mortality }\end{array}$ \\
\hline 16.0 & 2 & 2 & 1 & 1 & 6 & & 60 & Moribund \\
\hline 25.0 & 2 & 1 & 3 & 3 & 9 & & 90 & Total mortality \\
\hline 50.0 & 2 & 3 & 3 & 2 & 10 & & 100 & Total mortality \\
\hline
\end{tabular}


Result from range findings experiment with kerosene toxicant revealed normal behaviour of fishes in the control aquaria. At the concentration $8.0 \mathrm{ml} / \mathrm{l}$, the fish exhibited erratic movement with $50 \%$ mean mortality recorded. The fish were weak with increased opercula movement at $16.0 \mathrm{ml} / \mathrm{l}$ concentration recording $60 \%$ mean mortality. At $25.0 \mathrm{ml} / \mathrm{l}$, the fish exhibited moribund behaviour with $90 \%$ means mortality. Total mortality was recorded within 96 hours of exposure at concentration of $50.0 \mathrm{ml} / \mathrm{l}$. These mortalities were recorded at intervals of 24,48 , 72 and 96 hours as shown in Table 1.

These mortalities were recorded at intervals of 24, 48, 72 and 96 hours against the concentrations used and presented in bar chart as shown in Fig. 4. The multiple bar chart revealed an increasing mean mortality with increasing concentrations of kerosene. The higher the concentrations of kerosene used or applied, the higher the mean mortality recorded from C. gariepinus.

Results of the impact of kerosene on the blood parameters of $C$. gariepinus are presented in Figs. 5-10. Fig. 5 revealed that there a significant decrease in pack cell volume counts for 8.0,
16.0, 25.0 and $50 \mathrm{ml} / \mathrm{L}$ groups $(p<0.05)$ compared to the control. Fig. 6 shows that there was an insignificant decrease inhaemoglobin counts for $80 \mathrm{ml} / \mathrm{L}(\mathrm{p}>0.050\}$ and significant decrease for $16,25.0$ and $50 \mathrm{ml} / \mathrm{L}$ groups $(p<0.05)$ compared to the control Fig. 7 shows that there was a significant decrease in white blood cells counts for 8.0, 16.0, 25.0 and $50.0 \mathrm{ml} / \mathrm{L}$ groups $(p<0.05)$ compared to the control. Fig. 8 revealed an insignificant increase in lymphocyte counts for $8.0 \mathrm{ml} / \mathrm{L}$ group $(p>0.05)$ and significant increase for 16.0, 25.0, and $50.0 \mathrm{ml} / \mathrm{L}$ group $(p<0.05)$ compared to the control. What this implies that, as the concentration increases, lymphocytes counts increases correspondingly. Fig. 9 also revealed there was insignificant decrease in neutrophil counts for 8.0 and $16.0 \mathrm{ml} / \mathrm{L}$ groups $(p>0.05)$ and significant decrease for 25.0 and $50.0 \mathrm{ml} / \mathrm{L}$ groups $(p<0.05)$ compared to the control. This means as the kerosene concentration increased, the neutrophil count decreased, while Fig. 10 shows a significant decrease in monocyte counts for 8.0 , 16.0, 25.0 and $50.0 \mathrm{ml} / \mathrm{L}$ groups $(p<0.05)$ compared to the control. This implies that even at the lowest concentration, kerosene toxicant had impact on the monocytes of the exposed fish as shown in Fig. 10.

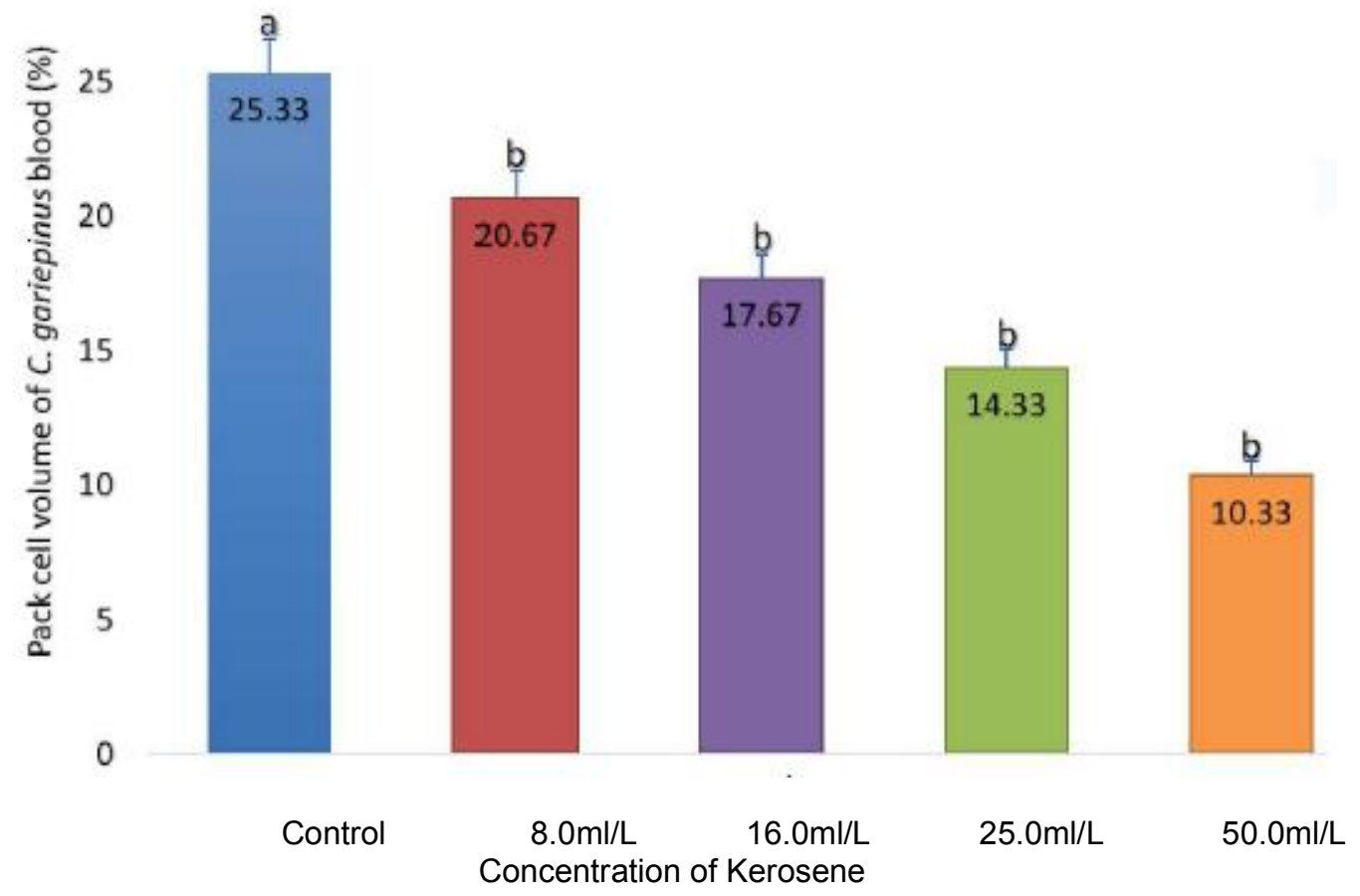

Fig. 5. Significant decrease of pack cell volume counts for $8.0,16.0,25.0$ and $50.0 \mathrm{ml} / \mathrm{L}$ group $(p<0.05)$ compared to the control 

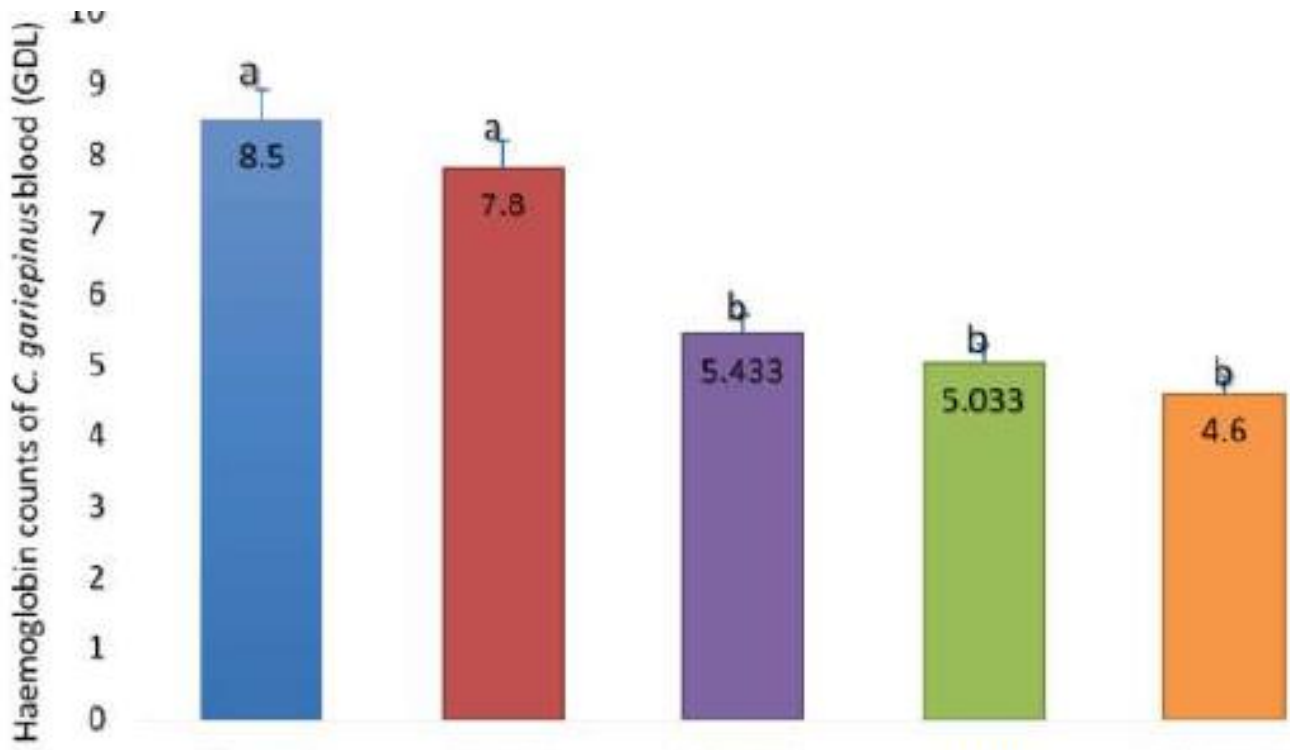

Control

$8 \mathrm{ML} / \mathrm{L}$

$16 \mathrm{ML} / \mathrm{L}$

$25 \mathrm{ML} / \mathrm{L}$

$50 \mathrm{ML} / \mathrm{L}$

Concentration of kerosene

Fig. 6. Insignificant decrease of haemoglobin counts for $80 \mathrm{ml} / L(p>0.050$ and significant decrease for $16,25.0$ and $50 \mathrm{ml} / \mathrm{L}$ groups $(p<0.05)$ compared to the control
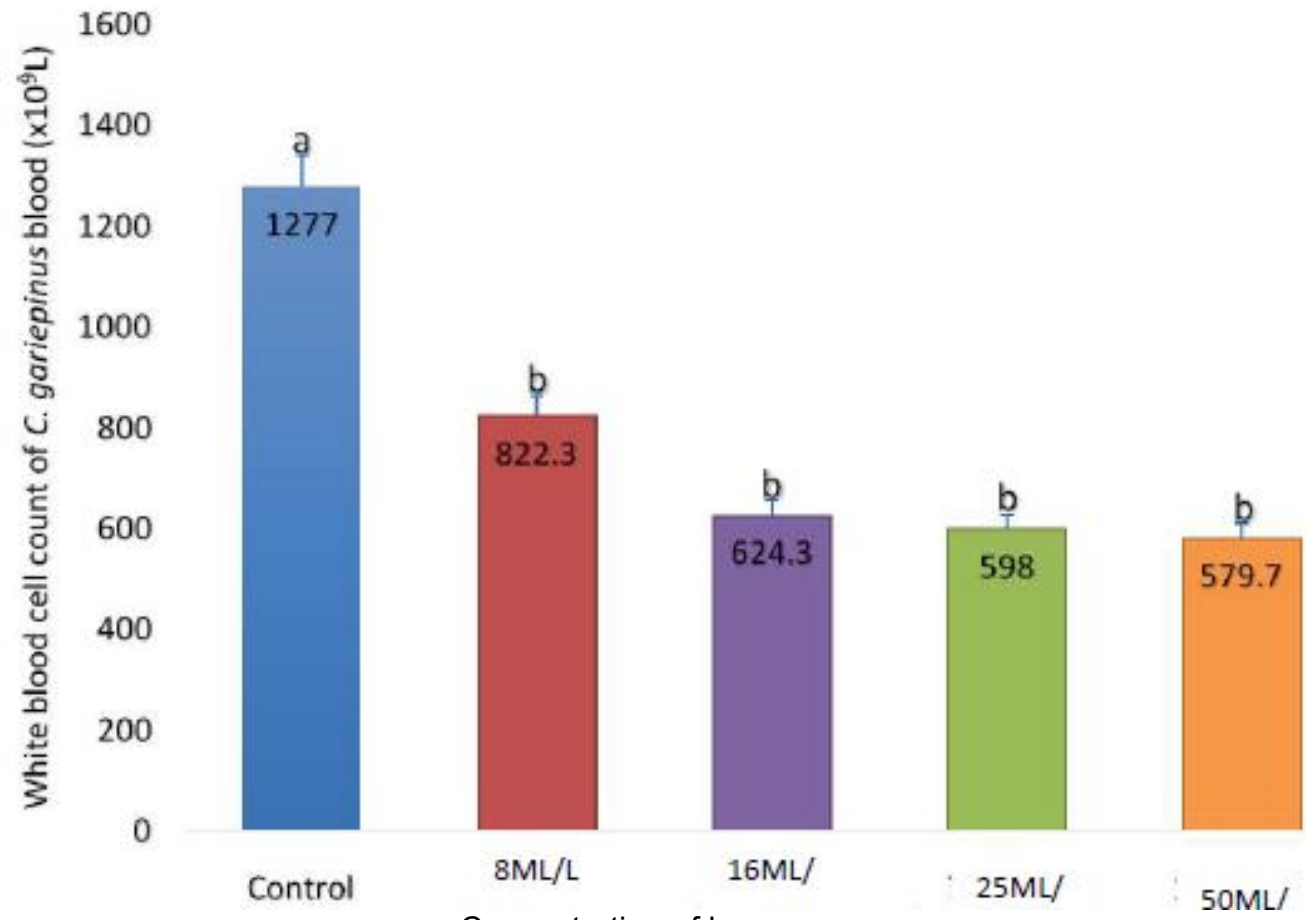

Concentration of kerosene

Fig. 7. Significant decrease of white blood cells counts for $8.0,16.0,25.0$ and $50.0 \mathrm{ml} / \mathrm{L}$ groups $(p<0.05)$ compared to the control 

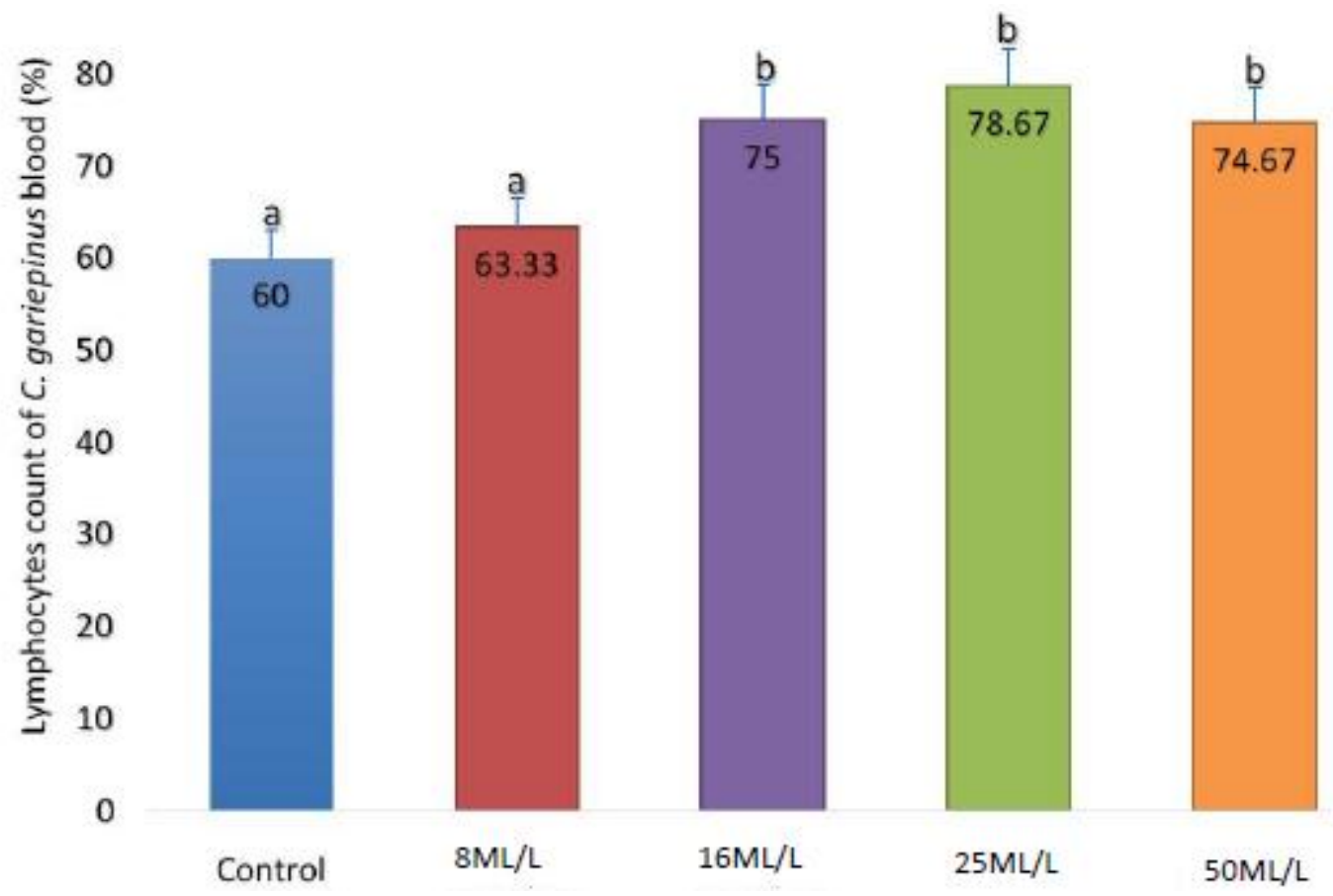

Fig. 8. Insignificant increase of lymphocyte counts for $8.0 \mathrm{ml} / \mathrm{L}$ group $(p>0.05)$ and significant increase for $16.0,25.0$, and $50.0 \mathrm{ml} / \mathrm{L}$ group $(p<0.05)$ compared to the control

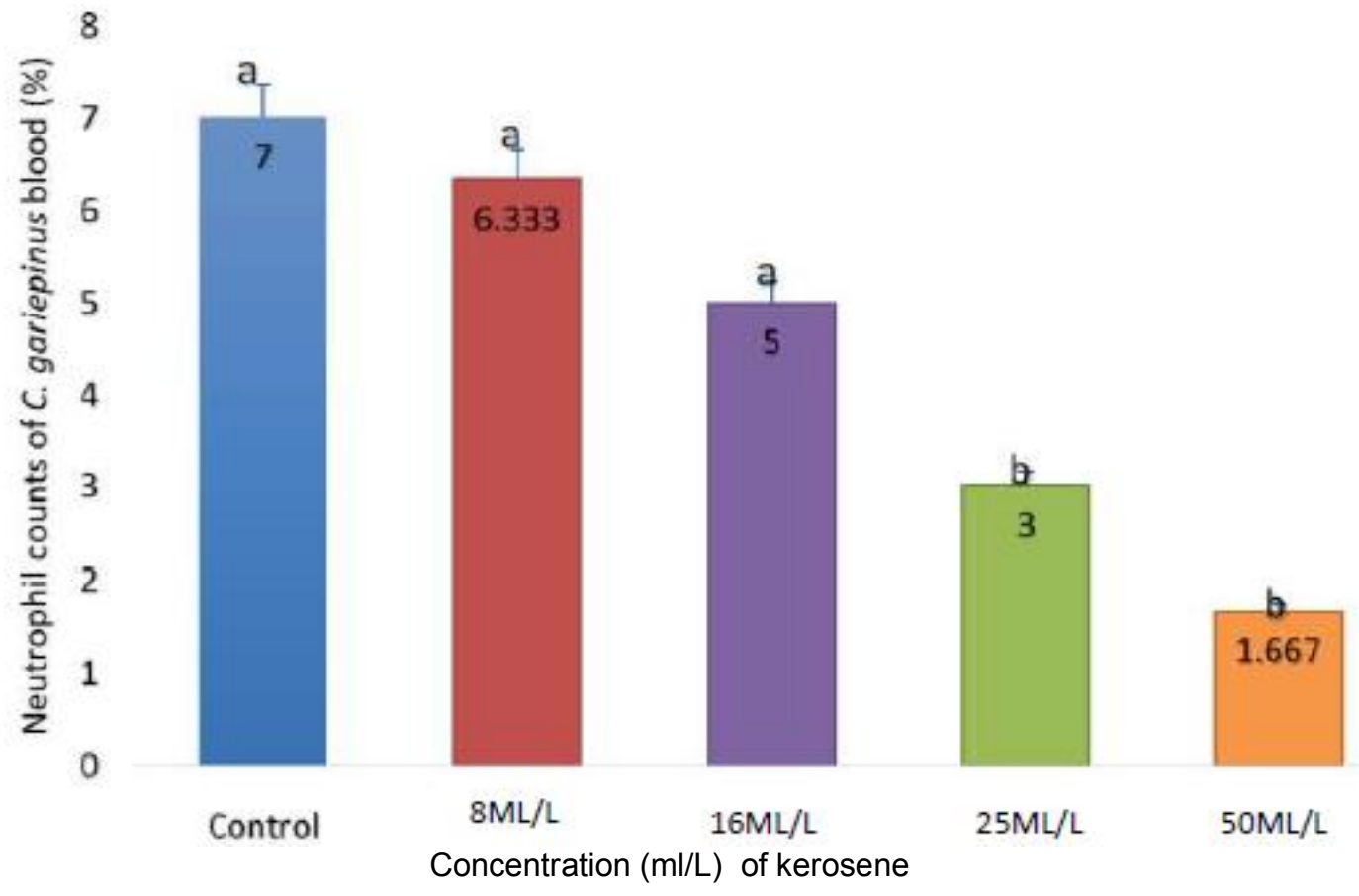

Fig. 9. Insignificant decrease of neutrophil counts for 8.0 and $16.0 \mathrm{ml} / \mathrm{L}$ groups $(p>0.05)$ and significant decrease for 25.0 and $50.0 \mathrm{ml} / \mathrm{L}$ groups $(p<0.05)$ compared to the control 


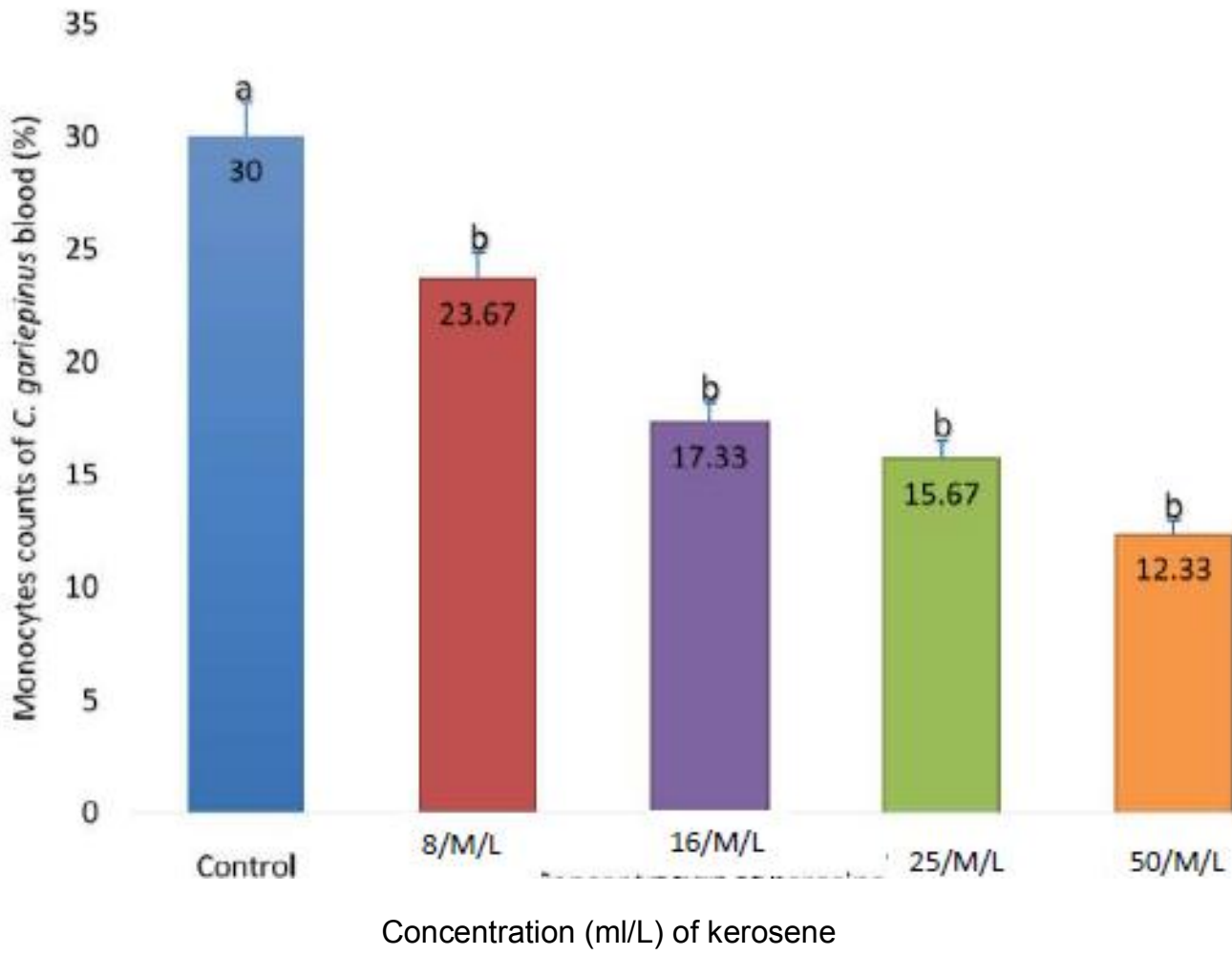

Fig. 10. Significant decrease of monocyte counts for $8.0,16.0,25.0$ and $50.0 \mathrm{ml} / \mathrm{L}$ groups $(p<0.05)$ compared to the control

The results of impact of kerosene on the blood cells hemolysis of $C$. gariepinus are presented in Fig. 11-15. Fig. 11 is lymphocytes and monocytes in control stained with haematoxylin. Figs. $12,13,14$ and 15 had various degrees of alteration and haemolysis when compared to control as indicated with arrows and shown in Fig. 11-15. Fig. 11 presents the lymphocytes and monocyte counts in the control experiment with kerosene treatment. Lymphocyte counts was $62 \%$ while monocyte count was $30 \%$. The value of monocytes decreased from 30 to 17 as the concentration of kerosene in the blood increased from 0.00 to $50 \mathrm{~m} / \mathrm{l}$ as depicted in Fig. 12. The rate hemoglobin in the red blood cells decreased from 5.3 in the control plate to 2.1 when the concentration of kerosene in the blood increased to $50 \mathrm{~m} / \mathrm{l}$ as shown in Fig. 13. Fig. 14 shows the effect of increased concentration of kerosene in neutrophils count of test fishes. Neutrophils counts decreased from 8.00 to $6.00 \%$ with increase in concentration of kerosene from 0.00 to $50 \mathrm{~m} / \mathrm{l}$ while Fig. 15 revealed the increase in lymphocyte cells from 62 to $77 \%$ with increase in concentration of kerosene in the blood from 0.00 to $50 \mathrm{~m} / \mathrm{l}$.

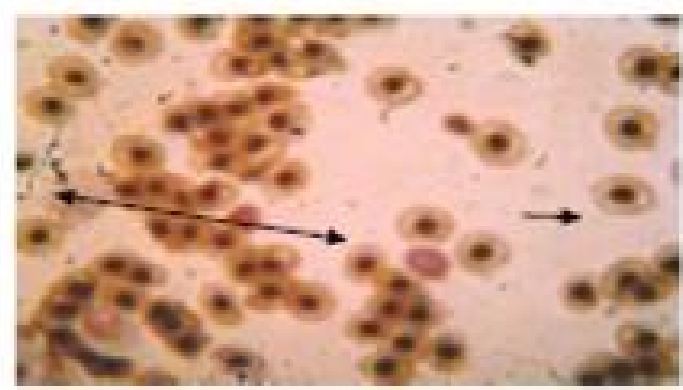

Fig. 11. Lymphocytes and Monocytes in Control

The results of effect of kerosene spills of $C$. gariepinushaematological parameters are presented in Table 2. Analyzed samples of blood of $C$. gariepinusexposed to kerosene were highly haemolyzed. The RBC value dropped from 5.3 (control) to $2.1 \mathrm{~mm} 3$ due to haemolysis. PCV dropped from $27 \%$ to $16 \%$. WBC value dropped from $1280 \times 109 / /$ to $602 \times 109 / /$, haemoglobin value dropped from $9.0 \mathrm{Gdl}$ (control) to $5.3 \mathrm{gdl}$. In the differential count, Lymphocyte value increased from $62 \%$ to $77 \%$, Neutrophil control 
value dropped from 8 to $6 \%$ while monocyte dropped from 30 percent to $17 \%$. All these alteration in values may not be unconnected with the effects of this toxicant (kerosene) on the blood profile of the test fish as shown in Table 2.

\section{DISCUSSION}

According to [25], Kerosene is a well-known fraction of hydrocarbon with a history of toxicity on land and aquatic life. Behavioural changes of

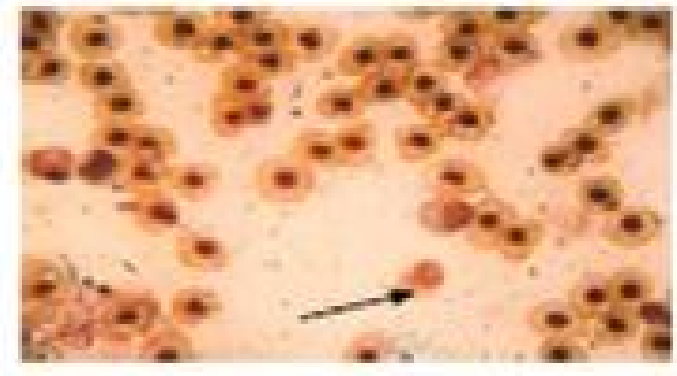

fish exposed to different concentration of kerosene were erratic movement, increase opercula movement, weakness, moribund behavior and death. These observations were not seen in the control. Mortality rate was directly proportional to increase in concentration. Total mortality was observed at $50 \mathrm{~m} / \mathrm{L}$ concentration within 96hrs exposure as shown on the LC50 probit curve in Fig. 13. Increase in opercula movement may not be unconnected with suffocation and gasping for breath as a result of toxicant impact on the fish [26].

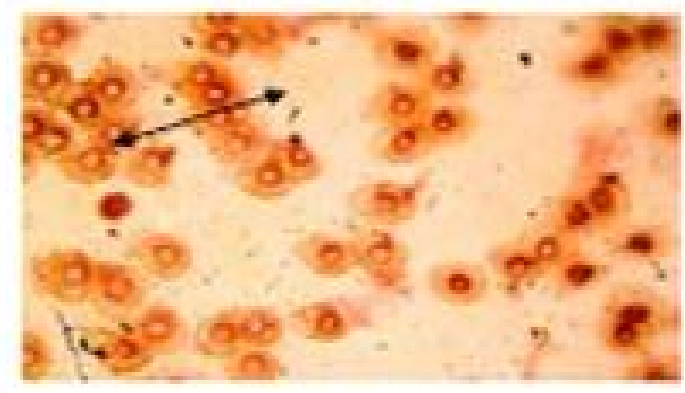

Fig. 12. Monocytes in $50 \mathrm{ml} / \mathrm{L}$ of kerosene (x10)

Fig. 13. Haemolyzed RBC (Arrow) in $50 \mathrm{ml} / \mathrm{L}$ of kerosene (x10)
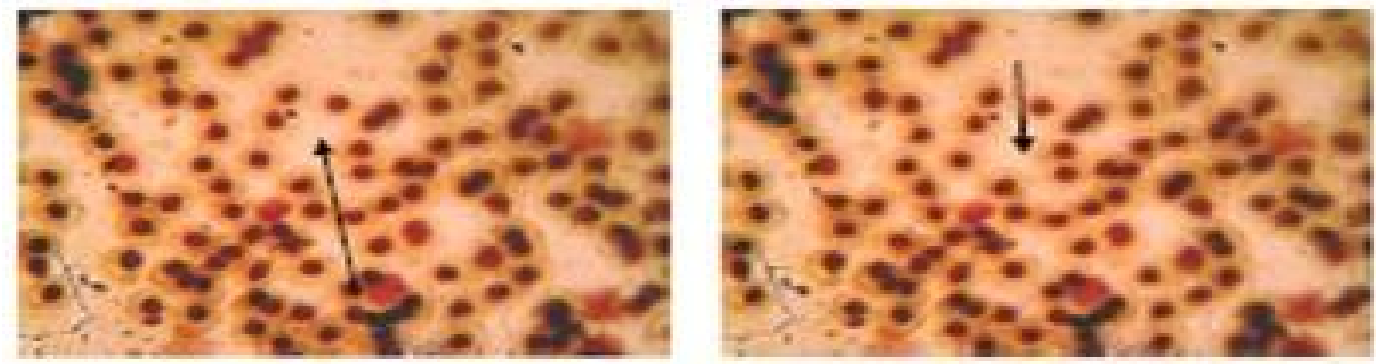

Fig. 14. Neotrophils (arrow) in $50 \mathrm{ml} / \mathrm{L}$ of kerosene $(\times 10)$

Fig. 15. Lymphocytes count (arrow) in $50 \mathrm{ml} / \mathrm{L}$ of kerosene (x10)

Table 2. Effect of toxicants (Kerosene) on the haematology of $C$ gariepinus

\begin{tabular}{|c|c|c|c|c|c|c|}
\hline $\begin{array}{l}\text { Treatment } \\
\text { Sample }\end{array}$ & $\begin{array}{l}\text { PCV } \\
(\%)\end{array}$ & $\begin{array}{l}\text { HB } \\
\text { (GDL) }\end{array}$ & Total WBC & $\begin{array}{l}\text { Differential } \\
\text { Count (\%) }\end{array}$ & $\begin{array}{l}\text { RBC } \\
\left(\mathrm{MM}^{3}\right)\end{array}$ & Remarks \\
\hline Control & 27 & 9.0 & $1280 \times 10^{9} \mathrm{~L}$ & $\begin{array}{l}L(62) \\
N(8) \\
M(30)\end{array}$ & 5.3 & Normal \\
\hline Kerosene & 16 & 5.3 & $602 \times 10^{9} \mathrm{~L}$ & $\begin{array}{l}\mathrm{L}(77) \\
\mathrm{N}(6) \\
\mathrm{M}(17)\end{array}$ & 2.1 & $\begin{array}{l}\text { Samples } \\
\text { were highly } \\
\text { Haemolyzed }\end{array}$ \\
\hline
\end{tabular}


Statistical analysis and graphical presentation showed the concentration at which $50 \%$ of the experimental fish are killed by the toxicant (kerosene) at $8 \mathrm{~m} / \mathrm{L}$. Graph and Bar chart of concentration against cumulative fish mortality exposed to kerosene at timely intervals $(24 \mathrm{~h}$, $48 \mathrm{~h}, 72 \mathrm{~h}$ and $96 \mathrm{~h}$ ) showed that mortality increased with increase in concentration as shown in Fig. 14. There was total mortality at concentration $50 \mathrm{~m} / \mathrm{L}$ of kerosene (which is the highest concentration used). Haematological analysis indicated severe haemolysis of the blood samples. Another stunning discovery was that the experimental fishes became severely anemic during blood samples collection. Haemolysis and Anaemia in fishes can be attributed to environmental factors, toxicants and pesticides according to $[27,28,29]$. Fluctuations in the RBC, WBC and differential counts readings as compared to the control could be caused by haemolysis and anaemia as a result of environmental factors, toxicants and pesticides [30]. The more pronounced observations during the experiment were severe laceration of the fish skin within $48 \mathrm{~h}$ of exposure.

Comparison of PCV, HB, WBC and RBC with the control showed decreased values and readings. This could have been caused by anaemia and haemolysis which agrees with $[31,32,33]$. A comparison of differential count (\%) between control and kerosene toxicant revealed elevated level of lymphocytes (lymphocytosis) and a decrease in monocyte count. This finding agrees with $[34,35,36,37]$. A comparison of total RBC (mm3) of the exposed fish with the control showed a drastic decrease in the RBC count.

Some studies have identified only a few individual aromatic compoundsin the juvenile fish livers [38] or bile [39] of fish that have been exposed to crude oil and a distillate fraction of petroleum that contains only a portion of the aromatic compounds found in the crude oil and absorbed in the fish causing different degrees of toxicity ranging from mild, acute to chronic toxicity of the petroleum fractions in the fish. The results of the present study is in line with this reports.

Toxicity of kerosene on the haematological parameters of the African catfish (C. gariepinus) sub adult was investigated. The experiment was conducted in triplicates of four treatments. Behavioral changes in fish exposed to different concentration of kerosene ranged from erratic swimming, moribund movement, jumping and lack of balance. Similar changes were not observed in the control throughout the experiment. This observation is similar to that of $[40,41,42]$. kerosene is composed of linear Alkyl Benzene Sulphonate (LABS), sodium tripolyphosphate (STPP), sodium carbonate, sodium sulphate, sodium perborate and sodium silicate (perfume) as active ingredients. The ability of these chemicals to cause behavioral changes in C. gariepinus has been reported by $[43,44]$ and $[45,46]$. In this present study, the fish were exposed to concentrations $8.0 \mathrm{ml} / \mathrm{L}$, $16.0 \mathrm{ml} / \mathrm{L}, 25.0 \mathrm{ml} / \mathrm{L}$ and $50.0 \mathrm{ml} / \mathrm{L}$. At $16 \mathrm{ml} / \mathrm{L}$ concentration, the mean mortality was $80 \%$ with an initial erratic swimming $[47,48]$ It was further observed that mean mortality increased drastically with increase in concentration of the crude oil pollutant $[49,50]$. At concentration $25.0 \mathrm{ml} / \mathrm{L}$, total mortality was observed within 72hours of exposure preceding moribund swimming while total mortality was observed in $50.0 \mathrm{ml} / \mathrm{L}$. The concentration at which $50 \%$ of the experimental fish were killed (LC50) was $8 . \mathrm{ml} / \mathrm{L}$. Results from statistical analysis indicated that mortality varied significantly with concentrations as higher values recorded higher mortalities. However, mean values showed highest mortality (74\%) with Kerosene [50].

A bar chart of concentration against cumulative fish mortality exposed to kerosene at timely intervals of $24 \mathrm{~h}, 48 \mathrm{~h}, 72 \mathrm{~h}$ and $96 \mathrm{hr}$ revealed that mortality increased as concentration increased. Total mortality of exposed fish was recorded mainly at $48 \mathrm{hr}$ and $96 \mathrm{hr}$ exposure. This finding corroborates with that of [50] and $[49,50]$.

Haematological parameter of the blood cells of the fish exposed to kerosene revealed severe haemolysis of the blood cells when viewed with a motic electron microscope at $\times 10$ magnification. Images from the control showed normal distribution of blood cells. Images from the histopathology of the blood cells revealed severe damages to the lymphocytes, monocutes, neutrophils and RBC cell counts respectively at $50 \mathrm{ml} / /$ concentration of kerosene whereas the control showed a normal distribution of lymphocytes and monocytes cell counts $[49,50]$. In all, a two way Analysis of variance on effect of kerosene toxicant with different concentrations on haematological parameters of the catfishes at the end of $96 \mathrm{hr}$ bioassay showed significantly different at $\mathrm{P}<0.05$ among the various concentrations studied. 


\section{CONCLUSION}

The degree of exposure of marine organisms to crude oil and its derivatives is becoming worrisome and a threat to food security and sustainability in most coastal regions and especially in the Niger Delta region of Nigeria where crude oil spillage has left the water bodies in the region unusable. This menace is usually and often accessed by measuring the body burden of crude oil and its derivatives like kerosene compounds, which are potentially harmful to aquatic life forms that utilize them in their livers and predominantly excrete them into bile. The pollution of water by petroleum effluents like kerosene and xenobiotics may play a major role in the decline of aquatic animals and fishes. Increasing awareness on the adverse effects of anthropogenic activities and crude oil fraction pollutants on aquatic environment should focused interest on health of fish populations and the possibilities to utilize these health parameters for assessing the quality of coastal aquatic environment. With the current threat to food availability and security post by the global COVID 19 pandemic, it thereforebecomes pertinent for all hands to be on deck to ensure the safety of aquatic life forms especially fishes, by minimizing aquatic pollution with crude oil derivatives like kerosene, to sustain fish food quality, availability and security.

\section{SIGNIFICANCE STATEMENT}

This study discovered and unveiled the sublethal toxicity and range testing of kerosene pollutant on aquatic life forms including fishes and other sea foods. The study revealed the toxic effects of water pollution by kerosene and xenobiotics and shows the major role it plays in the decline of aquatic animals and fishes interms of the damage to their hematological indices. Thus the study will increase awareness on the adverse effects of kerosene pollutants on aquatic environment and advocate for a focused interest on health of fish populations and the possibilities to utilize these health parameters for assessing the quality of coastal aquatic environment. This study will help researcher to uncover the critical impact of kerosene pollutant that many researchers were not able to explore.

\section{COMPETING INTERESTS}

Authors have declared that no competing interests exist.

\section{REFERENCES}

1. Dickman MD, Leung KM. Mercury and organochlorine exposure from fish consumption in Hong Kong. Chemosphere journal. 1998;2(4):12-18.37(5):991-1015.

Available:http://www.sciencedirect.com/sci ence/article/pii/S004565359800006X?via\% 3Dihub

2. Areola FO. Fish marketing and export potentials of fish and fisheries products in Nigeria. In: Educative and Informative Aqua-cultural Workshop and Exhibitions Tagged: Sustainable fisheries livelihood: Management and food security in Nigeria, Lagos, Nigeria. Ibadan, Nigeria: University of Ibadan. 2007;23.

3. Shaikh ZA, Vu TT, Zaman K. Oxidative stress as a mechanism of chronic cadmium-induced hepatotoxicity and renal toxicity and protection by antioxidants. Toxicol. Appl. Pharmacol. 1999; 154(3):256-63.

[cited 2017 Mar 10]

Availablefrom: http://www.sciencedirect.co m/science/article/pii/S0041008X98985866 ?viaDihub

4. Rani AU. Cadmium-induced bioaccumulation in the selected tissues of freshwater teleost, Oreochromis mossambicus (Tilapia). Ann N.Y. AcadSci; 2000;919:318-20.

[cited 2017 Mar 11];

Available: http://onlinelibrary.wiley.com/doi/ 10.1111/j.1749-

6632.2000.tb06895.x/abstract

5. Naigaga I, Kaiser $H$, Muller WJ, Ojok L, Mbabazi D, Magezi G, Muhumuza E. Fish as bioindicators in aquatic environmental pollution assessment: a case study in Lake Victoria wetlands, Uganda. PhysChem Earth. 2011;36(14-15):918-28.

[cited 2017 Mar 11];

Available:http://www.sciencedirect.com/sci ence/article/pii/S1474706511001823

6. Rosso JJ, Schenone NF, Perez Carrera AP, Cirelli AF. Concentration of arsenic in water, sediments and fish species from naturally contaminated rivers. Environ Geochem Health. 2013; 35( 2):201-14.

[cited 2017 Mar 11];

Available:https://link.springer.com/article/1 0.1007\%2Fs10653-012-9476-9

7. Authman MM, Zaki MS, Khallaf EA, Abbas $\mathrm{HH}$. Use of fish as bio-indicator of the effects of heavy metals pollution. J Aquac Res Dev. 2015;6:328-40. 
[cited 2017 Mar 11];

Available:https://www.omicsonline.org/ope n-access/use-of-fish-as-bioindicator-of-theeffects-of-heavy-metals-pollution-21559546-1000328.php?aid=47054

8. Begum A, Amin N, Kaneco S, Ohta K. Selected elemental composition of the muscle tissue of three species of fish, Tilapia

nilotica, Cirrhinamrigala and Clariusbatrach us, from the fresh water Dhanmondi Lake in Bangladesh. Food Chem. 2005;93( 3):439- 43.

[cited 2017 Mar 11];

Available:http://www.sciencedirect.com/sci ence/article/pii/S0308814604007617 Subs cription required to view

9. Mondon JA, Duda S, Nowak BF. Histological, growth and 7-ethoxyresorufin O-deethylase (EROD) activity responses of greenback

flounder Rhombosoleatapirina to

contaminated marine sediment and diet. AquatToxicol. 2001;54(3-4):231- 47.

[cited 2017 Mar11];

Available:http://www.sciencedirect.com/sci ence/article/pii/S0166445X01001461 Subs cription required to view.

10. Flora SJ, Mittal M, Mehta A. 2008. Heavy metal induced oxidative stress \& its possible reversal by chelation therapy. Indian J Med Res. 2008;128(4): 501- 23. DOl.org/10.1111/ijm.0022-3646.2008.02193x

11. Jaishankar $M$, Tseten $T$, Anbalagan $N$, Mathew BB, Beeregowda KN. Toxicity, mechanism and health effects of some heavy metals. InterdiscipToxicol. 2014;7(2):60-72.

[cited 2017 Mar 11];

Available:https://www.degruyter.com/view/j /intox.2014.7.issue-2/intox-20140009/intox-2014-0009.xml

12. Parasuraman S. Toxicological screening. J Pharm Pharmacother. 2011;2(2):74- 9. [cited 2017 Mar 11];

Available:https://www.ncbi.nlm.nih.gov/pm c/articles/PMC3127354/

13. Siroka Z, Drastichova J. Biochemical markers of aquatic environment contamination - cytochrome P450 in fish. a review. Acta Vet Brno. 2004;73:123-32. [cited 2017 Mar 12];

Available:https://actavet.vfu.cz/media/pdf/a vb_2004073010123.pdf

14. Murray GI, Barnes TS, Sewell HF, Ewen SW, Melvin WT, Burke MD. The immunocytochemicallocalisation and distribution of cytochrome P-450 in normal human hepatic and extrahepatic tissues with a monoclonal antibody to human cytochrome P-450. Br J Clin Pharmacol. 1988;25(4):465-75.

[cited 2017 Mar 12];

Available:https://www.ncbi.nlm.nih.gov/pm c/articles/PMC1387809/

15. deWaziers I, Cugnenc PH, Yang CS, Leroux JP, Beaune PH. Cytochrome P 450 isoenzymes, epoxide hydrolase and glutathione transferases in rat and human hepatic and extrahepatic tissues. J Pharmacol Exp Ther. 1990;253(1):38794.

[cited 2017 Mar 12];

Available:http://jpet.aspetjournals.org/conte nt/253/1/387.long

16. Otto DM, Moon TW. Phase I and II enzymes and antioxidant responses in different tissues of brown bullheads from relatively polluted and non-polluted systems. Arch Environ Contam Toxicol. 1996;31(1): 141-7. [cited 2017 Mar 12];

Available:https://link.springer.com/article/1 0.1007/BF00203918 Subscription required to view.

17. Bello SM, Franks DG, Stegeman JJ, Hahn $\mathrm{ME}$. Acquired resistance to Ah receptor agonists in a population of Atlantic killifish (Fundulusheteroclitus) inhabiting a marine superfund site: in vivo and in vitro studies on the inducibility of xenobiotic metabolizing enzymes. Toxicol Sci. 2001;60(1):77- 91.

[cited 2017 Mar 12];

Available:https://academic.oup.com/toxsci/ article/60/1/77/1686503/Acquired-

Resistance-to-Ah-Receptor-Agonists-in-a

18. Celander M, Leaver MJ, George SG, Forlin L. Induction of cytochrome P450 $1 \mathrm{~A} 1$ and conjugating enzymes in rainbow trout (Oncorhynchusmykiss) liver: a time course study. Comp Biochem Phys C. 1993;106(2):343-9.

[cited 2017 Mar 12];

Available:http://www.sciencedirect.com/sci ence/article/pii/074284139390144A

19. van der Oost R, Beyer J, Vermeulen NP. Fish bioaccumulation and biomarkers in environmental risk assessment: a review. Environ Toxicol Pharmacol. 2003;13(2):57- 149.

[cited 2017 Mar 12]; 
Available:http://www.sciencedirect.com/sci ence/article/pii/S1382668902001266

20. Joshi PK, Harish D, Bose M. Effect of lindane and malathion exposure to certain blood parameters in a fresh water teleost fish Clariasbatrachus. Pollut Res. 2002;21(1):55- 7.

21. Helrich K. Official methods of analysis [Internet]. 15th

VA: Association of Chemists. 1990;771.

[cited 2017 Mar 13].

Available:https://law.resource.org/pub/us/cf r/ibr/002/aoac.methods.1.1990.pdf

22. Olowu RA, Ayejuyo OO, Adewuyi GO, Adejoro IA, Denloye AA, et al. Determination of heavy metals in fish tissues, water and sediment from Epe and Badagry Lagoons, Lagos, Nigeria. E-J Chem. 2010;7(1):215-21.

[cited 2017 Mar 13];

Available:https://www.hindawi.com/journals /jchem/2010/676434/abs/

23. Habig WH, Pabst MJ, Jakoby WB. Glutathione S-transferases. The first enzymatic step in mercapturic acid formation. $\mathrm{J}$ Biol Chem. 1974;249(22):7130- 9.

[cited 2017 Mar 13];

Available:http://www.jbc.org/content/249/2 2/7130.full.pdf

24. Adewale IO. andAfolayan, A. 2005. Organ distribution and kinetics of Glutathione transferase from African river prawn, Macrobrachiumvollenhovenii (Herkl ots). Aquat Toxicol. 2005;71(2): 193- 202. [cited 2017 Mar 13];

Available:http://www.sciencedirect.com/sci ence/article/pii/S0166445X04003121

25. $\mathrm{Xu} J$, Yuan $X$, Lang $P$. The determination of enzymic activity and its inhibition on catalase by ultraviolet spectrophotometry. Environ Chem. Chinese.1997;16(1):73- 6.

26. Akinsiku OT, Agboola FK, Kuku A, Afolayan A. Physicochemical and kinetic characteristics of rhodanese from the liver of African catfish Clariasgariepinus Burchell in Asejirelake. Fish Physiol Biochem. 2010;36(3):573- 86. [cited 2017 Mar 13]

Available:https://link.springer.com/article/1 0.1007\%2Fs10695-009-9328-4

27. Aladesanmi OT, Okonji RE, Kuku A. The purification and some properties of rhodanese from tortoise (Kinixyserosa,
Schweigger) liver. Int J Biol Chem Sci. 2009;3(5):880- 9.

[cited 2017 Mar 13

Available:http://www.ajol.info/index.php/ijbc s/article/view/51053

28. Taniguchi T, Kimura T. Role of 3mercaptopyruvate sulfurtransferase in the formation of the iron-sulfur chromophore of adrenal ferredoxin. Biochim Biophys Acta. 1974;364(2):284- 95.

[cited 2017 Mar 13];

Available:http://www.sciencedirect.com/sci ence/article/pii/000527447490014X

29. Emuebie OR, Olaoluwa PM, Adenike K, Titilayo AO. The distribution of cyanide detoxifying enzymes (rhodanese and 3mercaptopyruvate sulphurtransferase) in different species of the family Cichlidae (Tilapia

zillii, Sarotherodongalilaeus and Oreochro misniloticus). Afr. J Biochem Res. 2010;4(6):163- 6.

[cited 2017 Mar 13];

Available:http://www.academicjournals.org/ article/article1380109112_Emuebie\%20et $\% 20$ alpdf

30. Bradford MM. A rapid and sensitive method for the quantitation of microgram quantities of protein utilizing the principle of protein-dye binding. Anal Biochem. 1976;72(1-2):248-54.

[cited 2017 Mar 13];

Available:http://www.sciencedirect.com/sci ence/article/pii/0003269776905273

31. Agboola FK, Okonji RE. Presence of rhodanese in the cytosolic fraction of the fruit bat (Eidolon helvum) liver. J Biochem Mol Biol. 2004;37(3):275- 81.

[cited 2017 Mar 13];

Available:http://citeseerx.ist.psu.edu/viewd oc/download?doi=10.1.1.926.1006\&rep=re p1\&type=pdf

32. World Health Organization. Guidelines for drinking water quality. Health criteria and other supporting information. Geneva, Switzerland: World Health Organization. 1996;2:94.

[cited 2017 Mar 14].

Available:http://www.who.int/water_sanitati on_health/dwq/2edvol2p1.pdf

33. Lamas S, Fernandez JA, Aboal J, Carballeira A. Testing the use of juvenile Salmotrutta L. as biomonitors of heavy metal pollution in freshwater. Chemosphere. 2007;67(2):221- 8.

[cited 2017 Mar 13]; 
Available:https://www.researchgate.net/pu blication/6632556_Testing_the_use_of_juv enile_Salmo_trutta_L_as_biomonitors_of heavy_metal_pollution_in_freshwater

34. Jovanovic B, Mihaljev Z, Maletin S, Palic D. Assessment of heavy metal load in chub liver (CyprinidaeLeuciscuscephalus) from the Nišava River (Serbia). Biologica Nyssana. 2011;2(1):518.

[cited 2017 Mar 13]

Available:http://journal.pmf.ni.ac.rs/bionys/i ndex.php/bionys/article/view/76

35. Obasohan EE. Heavy metals concentrations in the offal, gill, muscle and liver of a fresh water mudfish (Parachannaobscura) from Ogba River, Benin city, Nigeria. Afr J Biotechnol. 2007;6(22):2620- 7 .

[cited 2017 Mar 13]

Available:http://www.ajol.info/index.php/ajb /article/view/58160

36. Benson NU, Etesin MU, Essien JP, Umoren IU, Umoh MA. Tissue elemental levels in fin-fishes from Imo River System, Nigeria: assessment of liver/muscle concentrations ratio. $\mathrm{J}$ Fish Aquat Sci. 2006;1(3): 277-83.

[cited 2017 Mar 13]

Available:http://scialert.net/fulltext/?doi=jfas .2006 .277 .283

37. Hogstrand C, Haux C. Binding and detoxification of heavy metals in lower vertebrates with reference to metallothionein. Comp Biochem Physiol C. 1991;100(1-2):137-41.

[cited 2017 Mar 13];

Available:http://www.sciencedirect.com/sci ence/article/pii/0742841391901400

38. Yilmaz F. The comparison of heavy metal concentrations ( $\mathrm{Cd}, \mathrm{Cu}, \mathrm{Mn}, \mathrm{Pb}$, and $\mathrm{Zn}$ ) in tissues of three economically important fish (Anguilla

anguilla, Mugilcephalus and Oreochromisni loticus) inhabiting Köycegiz Lake-Mugla (Turkey). Turk J Sci Technol. 2009;4(1):715.

[cited 2017 Mar 13];

Available:http://www.akuademi.net/de/FIR AT_TJST/2009_01_01.pdf

39. Ekpo KE, Asia IO, Amayo KO, Jegede DA. Determination of lead, cadmium and mercury in surrounding water and organs of some species of fish from Ikpobariver in Benin city, Nigeria. Int J Phys Sci. 2008;3(11):289-92.

[cited 2017 Mar 14];
Available:http://www.academicjournals.org/ journal/IJPS/article-

abstract/D1AC2BB15013

40. Edem CA, Osabor V, Iniama G, Etiuma R, Eke J. Distribution of heavy metals in bones, gills, liver and muscles of (Tilapia) Oreochromisniloticus from Henshaw Town Beach Market, in Calabar, Nigeria. Pak J Nutr. 2009;8(8):1209- 11. [cited 2017 Mar 14];

Available:http://scialert.net/abstract/?doi=pj n.2009.1209.1211 [Crossref]

41. Adefemi SO, Asaolu SS, Olaofe O. Determination of heavy metals in Tilapia mossambicus fish, associated water and sediment from Ureje Dam in SouthWestern Nigeria. Res $J$ Environ Sci. 2008;2( 2):151- 5 .

[cited 2017 Mar 14];

Available:http://scialert.net/abstract/?doi=rj es.2008.151.155[Crossref]

42. Kakuku SE, Osibanjo O. Trace heavy metal pollution status in sediments of Niger Delta area. J Chem Soc Niger. 1988;13:911.

DOI: $10.0023 / \mathrm{jcsn} / 23412-234$

43. Murugan SS, Karuppasamy R, Poongodi K, Puvaneswari S. Bioaccumulation pattern of zinc in freshwater fish Channapunctatus (Bloch.) after chronic exposure. Turk J Fish Aquat Sci. 2008;8:55- 9 .

Available:http://www.trjfas.org/uploads/pdf 589

44. Adeyeye El, Akinyugha NJ, Fesobi ME, Tenabe VO. Determination of some metals in Clariasgariepinus (Cuvierand Vallenciennes), Cyprinuscarpio (L.) and Oreochromisniloticus (L.) fishes in a polyculture fresh water pond and their environments. Aquac. 1996;147( 34):205- 14.

Doi.org./10.002.32333/as.1268

45. Chen $\mathrm{MH}$, Chen $\mathrm{CY}$. Bioaccumulation of sediment-bound heavy metals in Grey Mullet, Liza macrolepis. Mar Pollut Bull. 1999;39(1-2):239- 44.

[cited 2017 Mar 14];

Available:http://www.sciencedirect.com/sci ence/article/pii/S0025326X99000272

46. Hovinga ME, Sowers M, Humphrey HE. Environmental exposure and lifestyle predictors of lead, cadmium, PCB, and DDT levels in Great Lakes fish eaters. Arch Environ Health. 1993;48(2):98- 104. [cited 2017 Mar 14]; 
Available:http://www.tandfonline.com/doi/a bs/10.1080/00039896.1993.9938402?src= recsys

47. Ivon EA, Ndome C. Comparative effects of detergents and liquid soaps on the African catfish (Clariasgariepinus) fingerlings in Calabar, Nigeria. Asian journal of Biology. 2016;2(4):12-18.

https://doi.org./10.9734/ajob/2016/v2i4010 2

48. Ndome C, Mowang DA, Ayibaerai TT. Comparative acute toxicity of local detergents (Omo and Ariel) on fingerlings of the Clariasgariepinus Heterbranchuslongifillsc hybrid. AACL Bioflux. 2013;6(4):413 - 420 . doi/abs/10.1111/jai.13877
49. Ivon EA, Ubi GM, Etangetuk NA, Anyanwu CO, Nkang NA, Ekanem AP. Toxic Potentials of Nittol Detergent on Haematological Parameters of African Catfish (Clariasgarienpinus) in Nigeria. Annual Research and Review in Biology. 2020;36(4):9-21.

DOI: $10.9734 / A R R B / 2020 / v 35 i 430212$

50. Ivon EA, Etangetuk NA, Ubi GM, Anyanwu CO, Nkang NA, Ekanem AP. Assessment of Histopathological Damages in African Catfish (Clariasgarienpinus) as influenced by Nittol Detergent Aquatic Pollution in Nigeria. Annual Research and Review in Biology. 2020;35(4):1-11.

DOI: 10.9734/ARRB/2020/v35i430206

(c) 2021 Ivon et al.; This is an Open Access article distributed under the terms of the Creative Commons Attribution License (http://creativecommons.org/licenses/by/4.0), which permits unrestricted use, distribution, and reproduction in any medium, provided the original work is properly cited.

Peer-review history:

The peer review history for this paper can be accessed here: https://www.sdiarticle4.com/review-history/69337 